\title{
EFFECT OF GENOTYPE, SIRE, SEX, GESTATION LENGTH ON BIRTH WEIGHT OF LAMBS
}

\author{
V. Caro Petrović ${ }^{1}$ M. P. Petrović ${ }^{1}$, Z. Ilić ${ }^{2}$, M. M. Petrović ${ }^{1}$, B. \\ Milošević ${ }^{2}$ D. Ružić Muslić ${ }^{1}$, N. Maksimović ${ }^{1}$ \\ ${ }^{1}$ Institute for Animal Husbandry, 11080 Belgrade-Zemun, Republic of Serbia \\ ${ }^{2}$ Faculty of Agriculture, Lesak, Republic of Serbia \\ Corresponding author: violycaro@yahoo.com \\ Original scientific paper
}

\begin{abstract}
The birth weight of lambs has an essential role in satisfying sheep production. Also reflected as primary factor later development of young organism. In the study included: gestation length, sire (two sires in each genotype during parenting), sex of lambs at birth, the birth weight of single lambs from well nourished mature ewes of the next genotypes: Miss (1), Wurttemberg (2) and Ile de France (3). The highest birth weight was obtained in genotype 3 with an average birth weight of $4.63 \mathrm{~kg}$ in sire 2 and $4.44 \mathrm{~kg}$ in sire 1 with a difference of $0.19 \mathrm{~kg}$. Gestation length of genotype 1 ranged from 144 to 153 days; genotype 2, from 148 to 154 days and the genotype 3 , from 144 to 151 days. The highest average birth weight in genotype 1 with gestation length of 153 days weighed $5.10 \mathrm{~kg}$. Average birth weights of male lambs in all genotypes were higher than the females. There were a very significant effect of genotype, sire, gestation length on birth weight of lambs $(\mathrm{P}<0.01)$, but sex have no significant effect on birth weight of lambs $(0.065 ; \mathrm{P}>0.05)$. The result achieved therefore can be explained that the effect of genotype, sire and gestation length and the interaction between subjects effects such as the next: Sire*Gestation length; Sire*Sex; Gestation length*Sex; Sire*Gestation length*Sex were highly and significantly affected the birth weight of lambs $(\mathrm{P}<0.01 ; \mathrm{P}<0.05)$. The interactions between subjects' effects will be a good indicator to be acquainted more on their influence in a certain trait.
\end{abstract}

Key words: lamb, birth weight, genotype, sire, sex, gestation length

\section{Introduction}

Lambs' birth weight has an important role in achieving a good sheep production (Petrovic et al., 2011) and speculated as a primary factor for the later development of young organism (Petrović, 2007). Vitality and mortality of lambs also brought about by the birth weight (Berhane and Arendonk, 2006; Vantankhah 
and Taleb, 2009). Other studies in animals showed that uterine capacity markedly influences birth weight (Jenkinson et al., 2007). The fetal growth and birth weight are regulated by genotype of the fetus, maternal genotype, maternal nutrition and the external environment and in the same way; the birth weight of the individual lambs was significantly related in their mothers' profile (Oldham et. al., 2011). Upon primary estimation of breeding values, must specified a model to find which best describe the biological processes wherein this requires study on non-genetic sources of variation that influence the specific measured trait concerned (Caro Petrović et al.,2013). Familiarity on such factors affecting variation in birth weight is especially important and conferred the affiliation between birth weight to neonatal and adult health (Gardner et al., 2007). Among the influencing factor affecting birth weight of lambs; environmental (year, season, etc.), the keeping and care during the production cycle, diet during stage of pregnancy in observed year and season. Apart from the said environmental factors, the mothers' age, type of birth and sex of lamb, i.e. factors that cannot be called environmental, but a certain biological category (Petrović et al., 2009). The weight of the dam at service significantly affected the birth weight of their lambs (Hussain et al., 2000). Indeed, the maternal body condition at mating and considering the energy intake prior to conception for at least the 6-8 weeks had significant effect on the birth weight of her lamb. Likewise energy intake of ewe's at late gestation, mostly important in terms of birth weight in sheep (Buttery et al., 2007). Wherefore, the birth weight is an easily measured and available substitute for the quantity of fetal growth. Aside from the reported factors which influenced the birth weight, other authors also reported the influence of gestation length on birth (Osinowo et al., 1994; Vatankhah et al., 2000; Fogarty et al., 2005) and can be longer for the dam's carrying male lamb (Vantakhah et al., 2000; Koyuncu et al., 2001; Fofarty et al., 2005). There was limited number of research about the effect of sire on lambs' birth weight, the interaction of sire breed $\times$ environmental category has significant effect for birth weight (Osorio-Avalos et al., 2012) and that this factor should require careful consideration in practical lamb husbandry as affirmed by Yagoob et al. (2004).

The aim of this paper is to investigate the influence of some fixed factors on the birth weight variability of lambs.

\section{Materials and Methods}

In the study, birth weight records of 180 lambs from 3 genotypes namely: Mis (1), Wurttemberg (2) and Ile de France (3). The ewes were conditioned before mating and fed in accordance with the farm practiced with hay and concentrates. The mating ratio was 30 ewes per sire per genotype (30:1:1) and for every genotype utilized 2 sire. The calculation for gestation length was based on the 
successful mating and lambing number of days. The following records were included in the investigation; gestation length, sire (two sires in each genotype during parenting), sex of lambs at birth, the birth weight of single lambs from well nourished mature ewes of a particular genotype. The statistical analysis was performed by using the SPSS software program with the next procedures: General linear model, univariate analysis of variance and between-subjects test and their interactions.

Linear model as presented below:

$$
\mathrm{Yijklm}=\mu+\mathrm{GTi}+\mathrm{SRj}+\mathrm{GLk}+\mathrm{SXl}+\varepsilon \mathrm{ijklm},
$$

where: Yijklmnop = birth weight of lth sex, kth gestation length, jth sire, and ith genotype

$\mu=$ overall population mean

$\mathrm{GTi}=$ effect of genotype (fixed effect -3 classes)

$\mathrm{SRj}=$ effect of sire (fixed effect -2 classes)

$\mathrm{GLk}=$ effect of gestation length (fixed effect -12 classes)

$\mathrm{SXl}=$ effect of sex of lamb (fixed effect -2 classes)

\&ijklm $=$ residual error

\section{Results and Discussion}

In table 1, can be viewed that the highest birth weight was obtained in genotype 3 with an average birth weight of $4.63 \mathrm{~kg}$ in sire 2 and $4.44 \mathrm{~kg}$ in sire 1 with a difference of $0.19 \mathrm{~kg}$, followed by genotype 1 sire 1 weighed $4.40 \mathrm{~kg}$ and sire 2 with $4.39 \mathrm{~kg}$ with a difference of $0.01 \mathrm{~kg}$ while in genotype 2 , sire $2 \mathrm{had} 4.05$ $\mathrm{kg}$ and in sire 1 was $3.63 \mathrm{~kg}$ for a difference of $0.42 \mathrm{~kg}$.

Table 1. Average birth weight of lambs per genotype and per sire

\begin{tabular}{|l|c|c|c|c|c|}
\hline Genotype & Sire & Mean & \multirow{2}{*}{ Std. Error } & \multicolumn{2}{|c|}{$95 \%$ Confidence Interval } \\
\cline { 5 - 6 } & & & & Lower Bound & Upper Bound \\
\hline \multirow{2}{*}{1.00} & 1.00 & $4.40^{\mathrm{a}}$ & .073 & 4.251 & 4.540 \\
\cline { 2 - 6 } & 2.00 & $4.39^{\mathrm{a}}$ & .069 & 4.257 & 4.530 \\
\hline \multirow{2}{*}{3.00} & 1.00 & $3.63^{\mathrm{a}}$ & .069 & 3.491 & 3.763 \\
\cline { 2 - 6 } & 2.00 & $4.05^{\mathrm{a}}$ & .067 & 3.915 & 4.180 \\
\hline & 1.00 & $4.44^{\mathrm{a}}$ & .087 & 4.270 & 4.782 \\
\cline { 2 - 6 } & 2.00 & $4.63^{\mathrm{a}}$ & .075 & 4.486 & \\
\hline
\end{tabular}

The gestation lengths of every genotype observed were in figure 1, wherein the gestation length of genotype 1 ranged from 144 to 153 days; genotype 2, from 148 to 154 days and the genotype 3, from 144 to 151 days. The highest average 
birth weight can be viewed in genotype 1 with gestation length of 153 days weighed $5.10 \mathrm{~kg}$; genotype 2 with $3.93 \mathrm{~kg}$ with gestation length of 153 days; genotype 3 with gestation length of 149 days weighed $4.80 \mathrm{~kg}$. Among these three genotypes investigated, two of them had similar gestation length that indicated the highest average birth weight within their group.

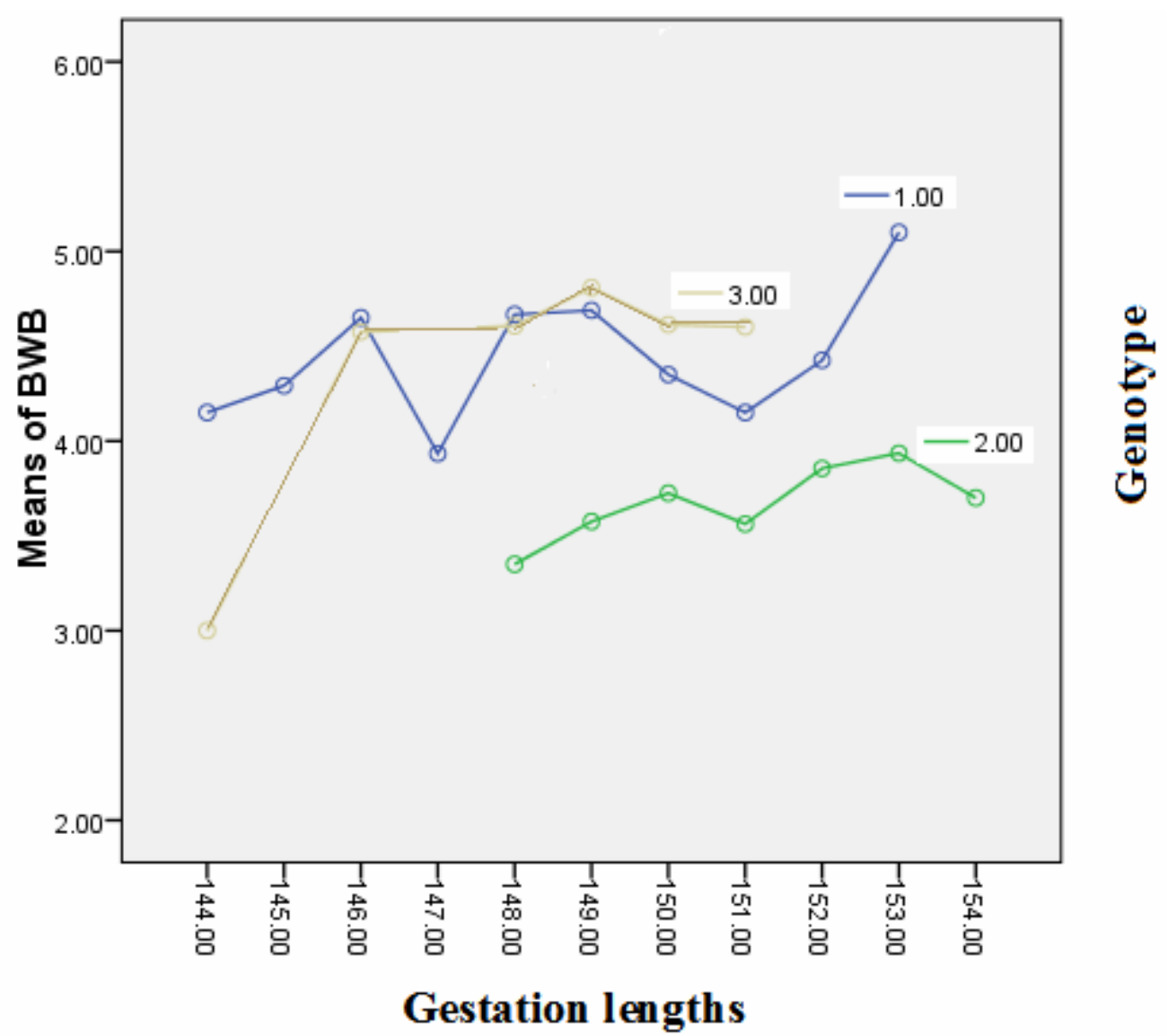

Figure 1. Effect of gestation lengths (days) on body weight at birth (BWB-kg)

As displayed in table 3, the average birth weights of male lambs in all genotypes were higher than the females. Among the weights of male lambs born, the highest birth weight was on genotype 3 followed by genotype 1 and lowest genotype 2 . For the lamb born female, the highest average birth weight was genotype 1 followed by genotype 3 and the lowest genotype 2 . 
Table 2. Average birth weight of lambs per genotype and sex

\begin{tabular}{|c|c|c|c|c|c|}
\hline \multicolumn{6}{|c|}{ Dependent Variable: BWB } \\
\hline \multirow{2}{*}{ Genotype } & \multirow{2}{*}{ Sex } & \multirow[t]{2}{*}{ Mean } & \multirow{2}{*}{ Std. Error } & \multicolumn{2}{|c|}{ 95\% Confidence Interval } \\
\hline & & & & Lower Bound & Upper Bound \\
\hline \multirow[t]{2}{*}{1.00} & 1.00 & $4.415^{\mathrm{a}}$ & .068 & 4.281 & 4.548 \\
\hline & 2.00 & $4.368^{\mathrm{a}}$ & .076 & 4.218 & 4.518 \\
\hline \multirow[t]{2}{*}{2.00} & 1.00 & $3.797^{\mathrm{a}}$ & .081 & 3.636 & 3.957 \\
\hline & 2.00 & $3.700^{\mathrm{a}}$ & .071 & 3.560 & 3.841 \\
\hline \multirow[t]{2}{*}{3.00} & 1.00 & $4.941^{\mathrm{a}}$ & .076 & 4.791 & 5.092 \\
\hline & 2.00 & $4.176^{\mathrm{a}}$ & .085 & 4.010 & 4.343 \\
\hline
\end{tabular}

Table 3. The test of between-subjects effects

\begin{tabular}{|c|c|c|c|c|c|}
\hline Source & $\begin{array}{l}\text { Type III Sum } \\
\text { of Squares }\end{array}$ & df & $\begin{array}{l}\text { Mean } \\
\text { Square }\end{array}$ & $\mathrm{F}$ & Sig. \\
\hline Corrected Model & $53.987^{\mathrm{a}}$ & 60 & .900 & 5.435 & .000 \\
\hline Intercept & 1605.767 & 1 & 1605.767 & 9699.684 & .000 \\
\hline Genotype & 11.129 & 2 & 5.564 & 33.612 & .000 \\
\hline Sire & 2.099 & 1 & 2.099 & 12.679 & .001 \\
\hline GesL & 5.259 & 10 & .526 & 3.177 & .001 \\
\hline Sex & .574 & 1 & .574 & 3.467 & .065 \\
\hline Genotype ${ }^{*}$ Sire & .393 & 1 & .393 & 2.372 & .126 \\
\hline Genotype * GesL & 4.969 & 10 & .497 & 3.001 & .002 \\
\hline Genotype * Sex & .064 & 2 & .032 & .194 & .824 \\
\hline Sire * GesL & 3.622 & 6 & .604 & 3.646 & .002 \\
\hline Sire * Sex & 1.926 & 1 & 1.926 & 11.631 & .001 \\
\hline GesL $*$ Sex & 3.407 & 9 & .379 & 2.286 & .021 \\
\hline Genotype $^{*}$ Sire $*$ GesL & 1.234 & 3 & .411 & 2.484 & .064 \\
\hline Genotype * Sire * Sex & .550 & 1 & .550 & 3.320 & .071 \\
\hline Genotype $*$ GesL $*$ Sex & .717 & 5 & .143 & .866 & .506 \\
\hline Sire * GesL * Sex & 2.678 & 4 & .669 & 4.044 & .004 \\
\hline Genotype * Sire * GesL * Sex & .077 & 1 & .077 & .467 & .496 \\
\hline Error & 19.700 & 119 & .166 & & \\
\hline Total & 3364.155 & 180 & & & \\
\hline Corrected Total & 73.687 & 179 & & & \\
\hline
\end{tabular}

As presented in table 3, the effect of genotype, sire, gestation length have a very significant effect on birth weight of lambs $(\mathrm{P}<0.01)$. On the said table, have shown that sex have no significant effect on birth weight of lambs $(0.065 ; \mathrm{P}>0.05)$. Meanwhile, the interaction between subjects effects such as the next: Sire*Gestation length; Sire*Sex; Gestation length*Sex; Sire*Gestation length*Sex were highly and significantly affected the birth weight of lambs $(\mathrm{P}<0.01 ; \mathrm{P}<0.05)$. In the study of Iyiola-Tunji et al. (2010) indicated that sex have no significant effect $(\mathrm{P}>0.05)$ on birth weight affirmed with ours but their result obtained on 
gestation length that had a low and non-significant relationship with birth weight $(0.114 ; \mathrm{P}>0.05)$ and lamb genotype $(-0.101 ; \mathrm{P}>0.05)$ were contradicting on that we obtained. Likewise, the findings of other authors namely: Yilmaz and Altin (2011); Caro Petrović et al. (2012); Ilić et al. (2013) in their investigation on birth weight affected $(\mathrm{P}<0.05)$ by sex of lambs.

Sharma et al., 2011 stated that the large genotype lambs were lighter and smaller when born to small genotype dams; however, the birth weight or body dimensions of small genotype lambs did not differ when born to large genotype dams. The differences in birth weight were reflected in differences in body dimensions between the groups of lambs. Probably, these statements can justify too our findings. Cloete et al. (1992) mentioned the significant effect of sire on birth weight. In the investigation of Olivier et al. (1987) they found that in variance term between sire were also significant for birth weight, likewise found variation between sires for type traits. Kincaid (1943) informed that "the sire could influence only the hereditary characters of the lambs; it can be appeared that in certain rams within each breed transmitted characters to their lambs which influenced birth weight", this remark supported the result attained in the study. Some authors reported that gestation length influenced lamb weight (Osinowo et al., 1994; Vatankhah et al., 2000; Fogarty et al., 2005) and can be longer for the dam's carrying male lamb (Vantakhah et al., 2000; Koyuncu et al.,2001; Fofarty et al., 2005). Thrift and Durr (1972) found out in their study that the sex of lamb was not a significant source of variation influencing gestation length but within each sex of lamb, the ewes with heavier lambs at birth had longer gestation length. Furthermore, for the ewes giving birth to single males had 1 day longer gestation length than ewes giving birth to single female lambs, but the difference was not significant. Babar et al. (2004), commented that the variation in birth weight reflected the level of management that bound to vary according to the ability of the farm manager and his capability", perhaps these annotation presumably must be considered too as additional support on the results of this study.

\section{Conclusion}

The result achieved therefore can be terminated that the effect of genotype, sire and gestation length and the interaction between subjects effects such as the next: Sire*Gestation length; Sire*Sex; Gestation length*Sex; Sire*Gestation length*Sex were highly and significantly affected the birth weight of lambs $(\mathrm{P}<0.01 ; \mathrm{P}<0.05)$. Precisely, understanding the influencing factors that affects the birth weight will lead changes in breeding and management schemes. Finally, the interactions between subjects' effects will be a good indicator to be acquainted more on their influence in a certain trait. Over and above, the birth weight of every 
genotype is useful information for farmers and for the animal breeder in order to be familiarized which fitted in their future needs.

\section{Acknowledgements}

This study is part of the projects TR 31053 "Modern biotechnology solutions in the breeding and feeding of cattle sheep and goats for the production of valuable and safety food" and TR 31001 "An environmental approach and implementation of modern biotechnologies as a basis for the improvement of ruminant breeding technology", and that are financially supported by the Ministry of Education, Science and Technological Development of the Republic of Serbia.

\section{Uticaj genotipa, oca, pola i trajanja bremenitosti na masu tela jagnjadi pri rođenju}

V.Caro Petrović, M. P. Petrović, Z. Ilić, M. M. Petrović, B. Milošević, D. Ružić Muslić, N. Maksimović

\section{Rezime}

Masa jagnjadi na rođenju ima bitnu ulogu u proizvodnji ovaca. Takođe se ogleda i kao primarni faktor kasnijeg razvoja mladog organizma. U radu su ispitivani sledeći faktori koji utiči na masu pri rođenju: genotip, otac, trajanje bremenitosti i pol. Istraživanje je obavljeno u populacijama Miss (1), Virtemberg (2) i Il de Frans (3). Najveća porođajna masa je dobijena kod genotipa 3 i to 4,63 $\mathrm{kg}$ od oca 2 i $4,44 \mathrm{~kg}$ od oca 1 , sa razlikom od $0,19 \mathrm{~kg}$. Trajanje bremenitosti genotipa 1 kretalo se u rasponu od 144 do 153 dana, genotipa 2 , od 148 do 154 dana i genotipa 3, od 144 do 151 dan. Najveća prosečna masa od $5,10 \mathrm{~kg}$ zabeležena je kod genotipa 1, sa trajanjem gestacije od 153 dana. Prosečne mase pri rođenju kod muških jagnjadi u svim genotipovima bile su veće od ženskih. Utvrđen je veoma značajan efekat genotipa, oca i trajanja bremenitosti na porođajnu masu jagnjadi $(\mathrm{P}<0,01)$, ali pol nije imao značajan uticaj na masu jagnjadi $(0,065 ; \mathrm{P}>0,05)$. Rezultati dobijeni u ovim istraživanjima pokazuju da su efekti genotipa, oca, trajanja bremenitosti i interakcije između efekata kao što su : otac * dužina bremenitosti; otac * pol; dužina bremenitosti * pol; otac * dužina bremenitosti * pol, vrlo značajno i značajno uticali na porođajnu masu jagnjadi $(\mathrm{P}<0,01, \mathrm{P}<0,05)$ ispitivanih genotipova. Interakcije između efekata su dobar 
pokazatelj boljeg upoznavanja njihovog uticaja na masu tela jagnjadi pri rođenju, koja je od ključnog značaja za kasniji razvoj mladog organizma.

\section{References}

BABAR M.E., AHMAD Z., NADEEM A., YAQOOB M. (2004): Environmental Factors Affecting Birth Weight in Lohi Sheep. Pakistan Vet. J., 24, 1, 5-8.

BERHAN A., ARENDONK J.V. (2006): Reproductive performance and mortality rate in Menz and Horro sheep following controlled breeding in Ethiopia. Small Rumin. Res. 63, 297-303.

CARO PETROVIĆ V., PETROVIĆ P M., PETROVIĆ M. M., ILIĆ Z., MAKSIMOVIĆ N., RUŽIĆ-MUSLIĆ D., STOLIĆ N. (2012): Estimation Of Phenotypic And Genetic Trends Of The Growth Traits In Lipska and Svrljig Sheep. Biotechnology in Animal Husbandry 28, 4, 743-749.

CARO PETROVIC V., PETROVIC P. M., ILIC Z., PETROVIC M. M., TENEVA A., STOJKOVIĆ J., RUZIĆ MUSLIĆ D. Some Non-Genetic Factors Influencing Early Growth Traits of Lambs. Poster presentation at the International Symposium held at Hotel Park Belgrade Serbia on October 2- 4, 2013.

CARO PETROVIĆ V., PETROVIĆ M.P., PETROVIĆ M.M., ILIĆ Z., STOJKOVIĆ J., RUŽIĆ-MUSLIĆ D., MAKSIMOVIC N. (2013): The Linear Relationship between Growth Traits Of Sharplanina Lambs In Extensive Farming Practices Biotechnology in Animal Husbandry 29, 2, 287-297.

GARDNER D.S., BUTTERY P.J., D. Z., SYMONDS M.E. (2007): Factors affecting birth weight in sheep: Maternal Environ. Reprod., 133, 297-307.

HUSSAIN A., BABAR M.E., ALI S., HASAN ZIA-UL (2000): Effect of Body Weight of Ewes on Birth Weight of Lambs on Rambouillet Breed of Sheep, Pakistan Journal of Biological Science 3, 1, 179-180.

ILIĆ Z., JEVTIĆ-VUKMIROVIĆ A., PETROVIĆ P.M., CARO PETROVIĆ V., MILOŠEVIĆ B., SPASIĆ Z., RISTANOVIĆ B. (2013): Effect of Mating Method, Sex and Birth Type On Growth Of Lambs. Biotechnology in Animal Husbandry 29, 2, 277-286.

IYIOLA-TUNJI A.O., AKPA B.I., NWAGU G.N., ADEYINKA I.A., OSUHOR C.U., LAWAL T.T., OJO O.A. (2010): Relationship between Gestation Length and Birth Weight in Nigerian Sheep and Their Crosses. Animal Production, 12, 3, 135138.

JENKINSON C.M.C., BLAIR H.T., KENYON P.R., HARDING J.E., BLOOMFIELD F.H., BREIER B.H., P. GLUCKMAN D. (2007): Maternal constraints in sheep breeds with diverse birth weight. Proc. N.Z. Soc. Anim. Prod., 67, 187-191. 
KINCAID C.M. (1943): Influence of the Sire on the Birth Weight of Lambs .Journal of Animal Science, 2, 152-156.

OLDHAM C.M., THOMPSON A.N., FERGUSON M.B., GORDON D.J., KEARNEY G.A., PAGANONI B.L (2011): The birth weight and survival of Merino lambs can be predicted from the profile of live weight change of their mothers during pregnancy. Animal Production Science, 51, 9, 776-783.

OSINOWO O.A., ABUBAKAR B.Y., TRIMNELL A.R. (1994): Genetic and phenotypic relationships between gestation length, litter size and litter birth weight in Yankasa sheep. Anim. Rep. Sci., 34, 2, 111-118.

OSORIO-AVALOS J., MONTALDO H.H., VALENCIA-POSADAS M., CASTILLO-JUÁREZ H., ULLOA-ARVIZU R. (2012): Breed and breed $x$ environment interaction effects for growth traits and survival rate from birth to weaning in crossbred lambs.Journal Animal Science, 90, 12, 4239-47.

PETROVIĆ P.M., RUŽIĆ- MUSLIĆ D., MAKSIMOVIĆ N., MEMIŠI N. (2009): Effect of Environmental and Paragenetic Factors On Birth Mass Variability of Mis Sheep Populations Biotechnology in Animal Husbandry, 25, 3-4, 213-219.

PETROVIC P.M. (2007): Sustainable sheep breeding (Monograph). Institute for Animal Husbandry Belgrade, p. 256.

PETROVIC P.M., RUZIC MUSLIC D., CARO PETROVIC V., MAKSIMOVIC N. (2011) Influence of environmental factors on birth weight variability of indigenous Serbian breeds of sheep. African Journal of Biotechnology, 10, 46734676.

SHARMA R.K., BLAIR H.T., JENKINSON C.M.C., KENYON P.R, COCKREM J.F., PARKINSON T.J. (2011): Uterine environment as a regulator of birth weight and body dimensions of newborn lambs. Journal Animal Science, 90, 1338-1348.

THRIFT F.A., DURR R.H. (1972): Relationship between Gestation Length of Artificially Inseminated Ewes and Number, Weight and Sex of Lambs Born. Journal Animal Science, 34, 3, 441-444.

VATANKHAH M., TALEBI M.A. (2009): Genetic and Non-genetic factors Affecting Mortality in Lori-Bakhtiari Lambs. Asian-Aust. J. Anim. Sci., 4, 459464.

YILMAZ M., ALTIN T. (2011): Growth characteristics in lambs of estrus synchronized ewes in grower conditions. Turk. J. Vet. Anim. Sci., 35, 6, 421-429.

YAQOOB M., MERRELL B.G., SULTAN I.J. (2004): Comparison of Three Terminal Sire Breeds For Birth Weight of Lambs Kept Under Upland Grassland Conditions In The Northeast Of England. Pakistan Vet. J., 24, 4, 196-198. 